\title{
A History of Pandemics Over the Ages and The Human Cost
}

\section{Abstract}

The present CoVid-19 pandemic has occupied our imagination and has affected our lives like never before. There had been pandemics before from ancient times that had profoundly affected and influenced human civilisation in every aspect known. Dynamics of pandemics have evolved as civilisation progressed and pandemics were often facilitated by technological advances. However, pandemics also were stark reminders of inequalities that have always existed in human society. Pandemics demand social distancing and social isolation for containment as they are spread by contagion and thus threaten human existence driven by a delicate social fabric.

This article traces the history of pandemics from the Roman times to the present day and presents an overview of these pandemics and their human cost.

Key words: Pandemic, plague, cholera, flu

\section{Full Text}

\section{Introduction}

We are living in unprecedented times with the CoVid-19 pandemic, times that occur once in generations. Apart from the human cost in lives and disease, a pandemic affects governments, infrastructure of countries, economy and most of all the very social fabric of civilisation that includes our values. The toll is widespread and affects the whole human race in all aspects of their existence. Pandemics repeat themselves forcing us to learn from our past and shape our present and future accordingly

Pandemic can be defined in epidemiological terms as "an epidemic occurring worldwide, or over a very wide area, crossing international boundaries and usually affecting a large number of people"1,2.
Soumit Dasgupta MBBS MS FRCS FRCP ${ }_{1}$ Rosa Crunkhorn MBBS

Alder Hey Children's NHS Foundation

Trust, Liverpool, UK;

1 Honorary Visiting Professor, Otology, University of Siena, Italy

\section{(a)}

Soumit.dasgupta@alderhey.nhs.uk

$\begin{array}{ll}\text { Article Information } \\ \text { Submitted } & 25.05 .2020 \\ \text { Pre-print } & 28.05 .2020\end{array}$

Cite as: Dasgupta, S., \& Crunkhorn, R. (2020) A history of pandemics through the ages and the human cost. The Physician 6(2) pre-print v1 ePub 29.05.2020 DOI: 10.38192/1.6.2.1
A pandemic or an epidemic is the affliction of the human race by invading microorganisms that infect humans leading to disease and in many instances death. The hallmark of an epidemic or a pandemic is its spread by contagion that is determined by the virulence of the organism concerned and by complex social, economic and political dynamics. This implies that the speed of spread can outstrip the efforts to contain it.

Marcus Aurelius, the philosopher emperor of Rome, who following the Antonine Plague in the Roman empire in 166 CE wrote: , "To bear in mind constantly that all of this has happened before and will happen again-the same plot from beginning to end, the identical staging."3. This observation resonates to this day.

This article traces the history of pandemics affecting the human race from the ancient world 
to present times and discusses the effect they had on our civilisation. We have selected only those where the estimated death toll was in excess of 100,000 and where the outbreak was a true pandemic crossing geopolitical boundaries or those pandemics that fit the WHO definition of 'the worldwide spread of a new disease'. Therefore we have not included either the small pox epidemic in the New World during the Spanish conquest or the Great Plague of London as although they had a huge toll in human lives, were still confined to geopolitical boundaries making them epidemics rather than pandemics. We have similarly left out small pox in 15th -19th century Europe as this was endemic rather than pandemic and had been identified since the times of Galen. We have further excluded HIV/AIDS that has killed an estimated 35 million people worldwide as the WHO considers it as a global epidemic rather than a pandemic.

Table 1 illustrates the different epidemics and pandemics since ancient times to the present day.

\section{The pandemics}

\section{The Antonine plague circa $165-180$ AD}

The Roman empire was at its height during the reign of Marcus Aurelius Antoninus who lodged successful campaigns in Dacia, Armenia and Parthia. The victorious Roman army returned with an infection that ravaged not only Rome but the empire and its vassals in Eastern and Western Europe and left 5 million people dead in its wake.

The direct fallout was an increased persecution of the Christians in the false belief that they started the pestilence and a severe curtailment of the mighty Roman army. In fact Commodus who succeeded Marcus Aurelius can be considered as the first emperor of the declining Roman Empire and the end of Pax Romana4. It also significantly affected Roman trade, especially with China, leading to a substantial drop in revenue and adding to the weakening of the empire. However, from the medical perspective, the association of Claudius Galenus, the court physician of Marcus Aurelius with the plague deserves special mention. His writings chronicling the symptoms and signs of the disease is a treatise de force on systematic study of medicine and from his descriptions, it appears that the disease could have been small pox rather than plague 5 .

2. The plague of Justinian, the first plague pandemic circa 541-542 AD

This plague was the classical Yersinia pestis bacterium transmitted through rodents. Justinian was one of the greatest of Roman emperors in Byzantium in eastern Europe and Asia with Constantinople as his capital at the height of his power. The organism was very likely imported from eastern Asia through Egyptian ports like Pelusium near present day Port Said as described by Procopius the historian 6 and then spread east. It devastated much of Europe and western Asia including the Sassanid empire in Persia. It decimated up to $40 \%$ of Constantinople's population and about $50 \%$ of the Eurasian population in three waves that continued until the 8th century - an estimated 30-50 million people.

This pandemic dealt a severe blow to Justinian's flourishing empire. There were hardly sufficient people to till the land, so agricultural output dropped dramatically. There was little land revenue coming in. The army was significantly weakened. The plague led to widespread revolts across the empire and heralded in 2 world orders - the rise of the Franks in western Europe and the rise of Islam in the middle east8. Procopius wrote, "All work slackened; craftsmen abandoned all their crafts and every task which any man had in hand."6. After 1.5 millennia, during the current CoVid-19 pandemic, this is a striking similarity.

Table 1: Pandemics/Epidemics since ancient times to present day; pandemics in italics 


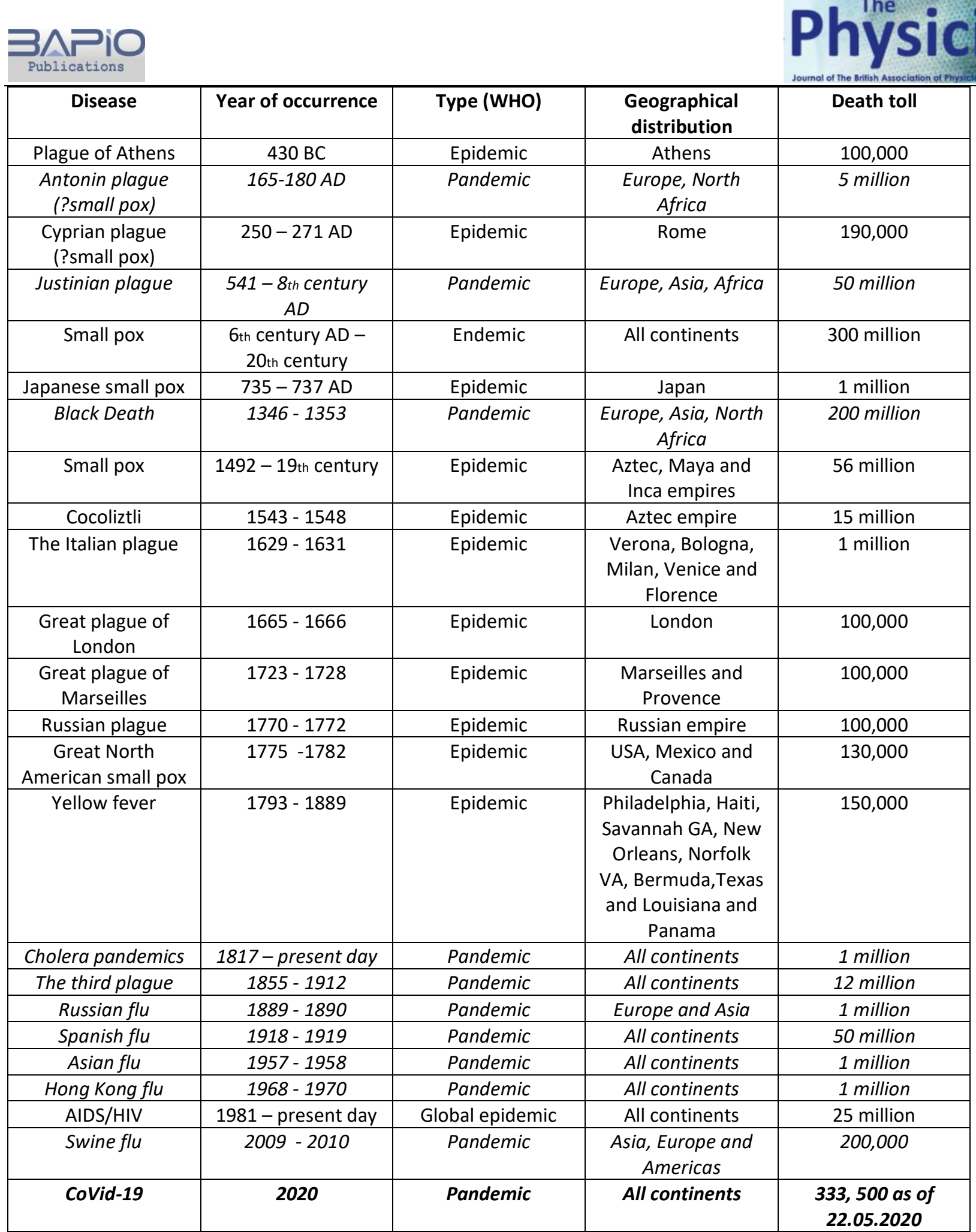

3. The Black Death, the second plague pandemic $1345-1353$

The plague that hit Justinian times did not extinguish completely but simmered. As with other pathogens the organism mutated and assumed a more virulent form.. It spread through the silk route in the medieval world from Mongolia and before sweeping across Asia, Europe and North Africa from 1345 leaving nearly 200 million dead and whole regions devastated. Boccacio's Decameron graphically merged passion and plague in 14th century 
Florence 10. Guy de Chaulliac, the eminent contemporary French surgeon wrote in 1363: "the father no longer visited the son or the son his father. Charity was dead and hope abandoned." 9. de Chaulliac's stark observation about suffering relationships rings a strange bell in 2020. Fear was all pervasive. The main sting of the second pandemic was over in 8 years but it regularly made its appearance as late as the early part of the 19th century throughout defined countries in Europe and Asia.

The effect of the Black Death was profound affecting every aspect of society. Governments raised taxes from the survivors. The poll tax or a charge on services was introduced that continue to this day in UK as the council tax. Agriculture ceased leading to a severe deficit in food stuff as the landed gentry could not employ labourers from the rural communities due to the sheer number of dead. The feudal world and serfdom took a significant back seat 11 as common folk exercised more choices as to who they would work for influencing the dynamics of labour. Minority persecution was at its peak. However, it also led to a development of public health services with improved sanitation and quarantine methods that eventually paid dividends in later outbreaks.

\section{The cholera pandemics 1817 - present day}

There have been six pandemics of cholera caused by the bacterium Vibrio cholerae spread by the fecal-oral route and the seventh one is still continuing. Cholera pandemic is a prime example as to how science and public health measures can control the spread of infection and with each pandemic, there were new discoveries as to the causation and more importantly how to contain it. As a result, death rates have dropped dramatically.

The first pandemic (1817-1823) originated in British India in the Gangetic basin and was exported from Calcutta in 1817, when the British East India Company had conquered much of India and life was relatively peaceful with no fresh new war looming. There was an influx of British personnel including military who came to
India after the Anglo-Mysore War in 1799 and to southeast Asia to maintain trading colonies. It struck these regions before making its way to the Mediterranean coast. The second pandemic (1829-1849) travelled to Russia and thence to Europe and finally through Irish immigrants to the Americas 12 .

The third pandemic $(1846$ - 1862), the most devastating of all, ravaged all continents. There was a reason for it. As Snowden 13 eloquently described, "the Industrial Revolution and its pathologies created favouring conditions. Cholera thrived on such features of early industrial development as chaotic and unplanned urbanization, rapid demographic growth, crowded slums with inadequate and insecure water supplies, substandard housing, an inadequate diet, ubiquitous filth, and the absence of sewers. When the vibrio disembarked in the port cities of Marseille, Hamburg, Valencia, and Naples, it found ideal conditions awaiting it." London was the melting pot of the colonies and here it was particularly virulent decimating nearly 23,000 lives in 1854 .

The fourth pandemic (1865 - 1875) spread through Muslim Haj pilgrims and hit Mecca first before spreading to Europe. The fifth pandemic $(1881$ - 1896) took its toll in Asia, South America and parts of Europe and Germany but spared USA and Britain due to improved sanitation and identification of the source with quarantine methods in force. By this time the organism had been identified by Robert Koch. The sixth pandemic (1899 - 1923) affected parts of North Africa, the middle east, Europe and most of all India. The current pandemic that started in 1961 originated in Indonesia and is still claiming lives albeit much less compared to before 15 . 
led to "mass flight, riot, social hysteria,

Cholera differs from other disease pandemics in three broad aspects. Firstly it was a 'class conscious' affliction and did not affect the well to do middle class or the rich. It was a disease exclusively confined to the lower middle class and the poor due to unhygienic living conditions. Secondly, its spread was facilitated by improved transport and the intense political turmoil ongoing in Europe at the time. Thirdly it generated more fear than plague in people as

Figure 1: Artistic depiction of plague - Saint Sebastian pleads with Jesus for the life of a gravedigger afflicted by plague during the Plague of Justinian. Josse Lieferinxe, c. 14971499, Walters Art Museum. (This work is in the public domain

https://commons.wikimedia.org/wiki/File:Plag uet03.jpg)

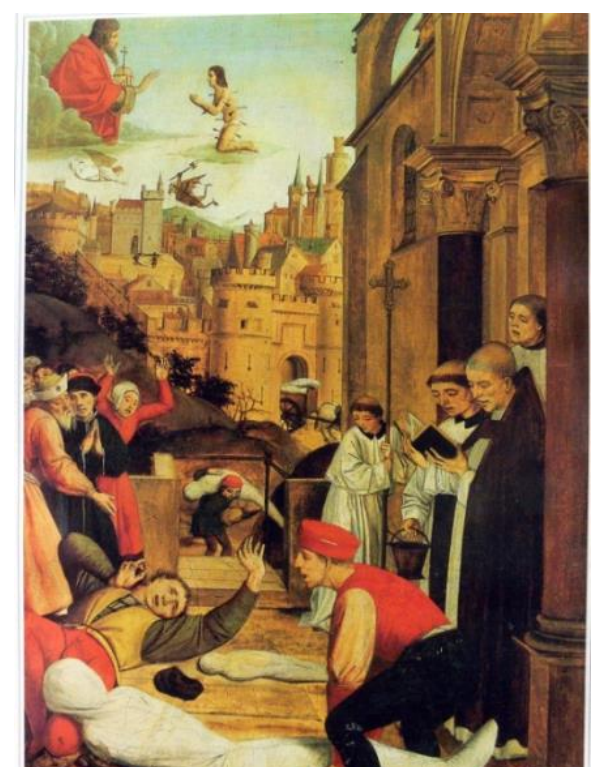

nearing death the human form adopted what can be called a 'death grimace' due to dehydration and the symptoms were often dramatic. Again in Snowden's words13, this terror

\section{The third plague (1855 - 1912)}

The third plague incorporated both the pneumonic and the bubonic variety of Yersinia scapegoating, and economic disruption". Cholera claimed a death tally of nearly 1 million and it is a great credit to the ingenuity of science that the death toll was not as high as plague.

John Snow in London in 1854 correctly identified a water pump in Soho as the source

of cholera and then quarantined the area leading to a drastic fall in deaths. William Brooke O'Shaughnessy, professor of chemistry in the nascent Calcutta Medical College propounded the theory of replacing dehydration by saline therapy in 1831 . This was followed up by Thomas Latta in 1832 who physically performed the experiment and published it but died of the disease14. The science of epidemiology blossomed and with it sanitation methods. The sewers of Paris and Naples to exclude human efflux were refurbished and rebuilt setting examples.

Plague, syphilis, tuberculosis and small pox have led to creativity and were depicted in arts in several ways as they involved all classes (Figure 1). Cholera was a filth that originated from the gutters and sewers in the lowest of human class and did not evoke much artistic movement. In Gabriel Garcia Marquez's Love in the Times of Cholera, cholera was only in the background 13. Compare this to Boccacio's Decameron where the central theme of his novel was the plague and how people reacted to it. Luchino Visconti in adapting Thomas Mann's 'Death in Venice' (1971) as a film kept cholera hovering in the background as an unwanted pest whereas Ingmar Bergman's 'The Seventh Seal' (1957) romanticised death from plague in a human form playing chess with a knight (Figure 2)

pestis. It originated in China in 1855, made its way to Hong Kong and finally erupted in 1894. A 
number of factors were responsible for its spread. Ease of transport, increased maritime trade in the colonies and increased demand for migrant labour facilitated its spread like wildfire in the east. Coupled with this were the stark poverty, lack of hygiene and sanitation that the populace in these parts faced.

When it reached Europe through the ports, the devastation was limited to these cities by the sea or river estuaries. In fact Europe was largely spared of much mortality or spread due to better sanitation, general health and stricter control of public health. It reached London in 1896 carried by two Indian sailors and within a few months, a conference on plague epidemiology concurred on public health measures to control the outbreak. Besides, the third plague like the cholera pandemics was mainly limited to only the poor classes 15 .

In India it was different. The pestilence hit India in 1896 and swept across the country from the ports especially Bombay. It was given much fuel by an emaciated and starving population already devastated by a famine due to prolonged draught in 1897 that decimated part of the population. It must be remembered that sanitation and sewerage disposal in big colonial metropolis like Bombay and Calcutta were literally non-existent. Dedicated underground sewerage work in the cities started in the 1870 s but were limited to the affluent parts and not in the slums. In addition, this teeming mass of humanity engaged in every trade imaginable requiring godowns for storage which bred the rats. Rodent density flourished and with it the fleas and the plague bacillus 13. Imbibed with the fruits of western industrial revolution, the wealthy had a vastly improved quality of life but the condition of the poor remained as they had been for centuries. Out of a total 12 million dead globally, India accounted for as much as $90 \%$.

This plague had a profound political impact in India. The British government enforced draconian sanitation measures and propagated a racial disharmony. The ruling class and the wealthy were not affected by the plague unlike the Justinian or the Black Death which led to the idea that the disease spared the white race by divinity. Further, these measures hurt traditional Indian religious sentiments. There was a violent back lash. The first political assassination in India in colonial times post 1857 Sepoy Rebellion took place in Pune in 1897 when three Chapekar brothers shot dead Rand, the Indian Civil Service plague inspector and Ayerst, his deputy. The brothers' execution inspired the armed struggle against British rule that continued until the $1930 \mathrm{~s}$ and finally culminated in the 1940s with the formation of the Indian National Army of Subhash Chandra Bose who contributed significantly to India's freedom. A similar political fallout during the third plague was in South Africa where segregation was strictly enforced in quarantine camps that probably led to Apartheid being adopted officially.

The plague also saw breakthroughs in medicine. The bacillus was discovered during this time by Yersin and Kitasato in 1894 and for the very first time vector transmission of disease was identifieds. The first systemic studies in immunology commenced and W Haffkine, a Ukrainian living in India developed a plague vaccine. Sanitation techniques were refined and there were 'rat hunting campaigns'. The disease smouldered and was finally extinguished in 1940. It however still remains in patches especially in Africa.

\section{The Flus $1889-2010$}

For the purposes of this article and for brevity, flu and influenza will be used interchangeably.

There had been several flu pandemics with evolving strains of the influenza virus over the last two centuries. The Russian flu pandemic in 1889 - 1890 started in Asia Minor and was imported to Russia especially St Petersburg via Constantinople. It then reached Paris in two months and engulfed the whole of Europe. The death toll was 1 million. This was a pandemic that was most rapidly spread as a result of increased world population and the massive transport 
revolution brought about by the railways. In addition, this was the first pandemic that was systemically covered with accurate epidemiological data in the press16.

The most well-known and intense flu pandemic from the number of dead point of view was the Spanish flu, so named as it was most reported in Spain who had been neutral during the first world war and was not subjected to wartime censorship2. Astonishingly the flu only lasted for 1 year from 1918 to 1919, yet it killed nearly 40 million people worldwide. The vast majority of mortality was in young adults. The death toll was attributed to secondary bacterial infections 17 and possibly a cytokine storm much like what is happening in the CoVid-19 pandemic.

The Spanish flu can be deemed as a collateral of the first world war. War obligated massive troop movements by enhanced transport and the setup of military camps all over Europe. It probably originated in a military base hospital for British troops in France in 1918, a camp that not only processed war casualties who may have been exposed to gas attacks, but also was regularly stocked by poultry and piggery to feed the troops18. The virus now identified as the H1N1 virus was later identified as spreading from human to swine to human17. The Spanish flu pandemic is often known as the 'forgotten pandemic' as it came and went like a cyclone and at a time in war ravaged Europe leaving no indelible memories or a fallout in different aspects. Research was rekindled in the 2000s leading up to the resurgence in 2009.

The next two flu pandemics involved the $\mathrm{H}_{2} \mathrm{~N}_{2}$ strain of the influenza virus and were dubbed as the Asian flu of 1957-58 and the Hong Kong flu of 1968-1970. They each claimed about 1 million people but they occurred in flourishing virology, bacteriology and epidemiological advances in science. Vaccination became a reality and it was likely that herd immunity had already developed by then. These two pandemics much like today's
CoVid-19 affected individuals with pre-existing lung disorders in the majority.

Our last discussion is about the very recent and contemporary swine flu outbreak of 2009-2010 that claimed an estimated 200,000 lives. Most of the readership of this article has probably lived through this pandemic. This was caused by the $\mathrm{H} 1 \mathrm{NI}$ influenza virus. A difficulty in writing about contemporary history is that the readership would have formulated their own opinions by first-hand experience rather than the historian pondering through voluminous past evidence to present a historical account. The flu originated probably in Asia or Mexico in pigs and then travelled through humans19. By this time science has several methods in its armamentarium to fight a pandemic and the death toll was kept at a minimum.

That brings us to the CoVid-19 pandemic. It is curious and fascinating to note as we have seen from the previous pandemics in this discourse, that CoVid-19 can be called a mixture of all pandemics from ancient times to the present day in terms of its effects on human civilisation and natural history of disease. Pandemic dynamics, in our view has reached its culmination. There will be future infectious disease pandemics but we believe that the epidemiological pattern will be similar. Unless of course, there is one strain of an organism unleashed in the future that will wipe out the human civilisation like a zombie apocalypse which is highly unlikely.

\section{The Human Cost}

Whilst infections of living organisms by another can be deemed as a natural phenomenon, yet pandemics are as a result of a paradox. They occur by the virtues and vices of human civilisation. They spread by technological advances in mobility and by inequality existing in mankind partly generated by the wealth that is a direct result of technology. Factors responsible for spread of pandemic include disease movement, novel mutations in the infectious organism, the virulence of the organism to which 
innate immunity has not developed due to its novel mutations and the difficulties in containment20. Like all natural disasters, pandemics cull the human population and probably maintain the eco balance in this fragile planet.

Pandemics will affect the health, the economy and the very delicate and sensitive social fabric of human society and lead to political redefinitions. Human social fabric is built around interacting with each other at close proximity to each other. A pandemic challenges that. As Dr Erin Myers in Steven Soderbergh's futuristic film 'Contagion' (2011) said, "The average person touches their face two or three thousand times a day...three to five times every minute. In between that we're touching doorknobs, water fountains, and each other - don't touch anyone"- that threatens our very existence as a race.

A new after effect of pandemics is the threat of bioterrorism. Technology has made possible the frightening thought that the organisms responsible for pandemics can be mutated artificially for a more virulent strain that can wreak havoc when unleashed. Whether human sense and sensibility has evolved with progression of civilisation is a complex topic to ponder and we can only hope that human ingenuity, intelligence and resilience to survive will overcome the devastating effects of any pandemic.

\section{Conclusions}

Throughout history, pandemics are integral parts of human civilisation regardless of how much we progress to beat them. The more we adapt to fight these, the more they adapt and evolve. Societies change, mind sets change, science is enriched and politics changes. What does not change is our will to survive as a race.

\section{References}

1. Harris, SS. A Dictionary of Epidemiology, Fourth Edition. 2000; Oxford University Press, New York

2. Morens, DM et al. What is a pandemic? J Infect Dis. 2009; 200: 1018-1021. doi: 10.1086/644537)
3. Marcus Aurelius. Meditations. Full text available at

athttp://classics.mit.edu/Antoninus/meditations. mb.txt accessed 19.05.2020 at 20.47pm

4. Edward Gibbon. Decline and Fall of the Roman Empire. 1988. Wordsworth Classics

5. Littman RJ, Littman LM. Galen and the Antonine Plague. The American Journal of Philology. 1973. 94: 243-255

6. Procopius. History of the Wars, Secret History, and Buildings. 1967. Trans. and ed. Averil Cameron New York: Washington Square Press Inc

7. Lotfy WM. Plague in Egypt: Disease biology, history and contemporary analysis: A minireview. Journal of Advanced Research. 2015; 6: $549-554$

8. Joshua North, "The Death Toll of Justinian's Plague and Its Effect on the Byzantine Empire," Armstrong Undergraduate Journal of History. 2013; 3

9. Wong TW and Fung KP. The Plague Pandemics and the Discovery of the Plague Bacillus. AsiaPacific Journal of Public Health 1988 - Vol2 No. 2

10. Levenstein J. Out of Bounds. Passion and the Plague in Boccaccio's Decameron. Italica. 1996; 73: 313-335

11. James T. Black Death: The lasting impact. 2011. http://www.bbc.co.uk/history/british/middle_ag es/black_impact_01.shtml accessed 18.5.2020 at 10.32am

12. https://www.cbc.ca/news/technology/cholera-sseven-pandemics-1.758504

13. Snowden FM. Epidemics and Society. Chapters 1,2,7 and 8. Yale University Press. 2019; https://www.jstor.org/stable/j.ctvqc6gg5.18

14. Latta T. The First Use of Intravenous Saline for the Treatment of Disease. International Journal of Epidemiology. 2013; 42: 387-390 https://doi.org/10.1093/ije/dyt045

15. Brabanti B, Dean KR et al. The Third Plague Pandemic in Europe. Proc. R. Soc. B. 286: 20182429. http://dx.doi.org/10.1098/rspb.2018.2429.

16. Kempińska-Mirosławska B., Woźniak-Kosek A. The influenza epidemic of 1889-90 in selected European cities - a picture based on the reports of two Poznań daily newspapers from the second half of the nineteenth century. Med Sci Monit, 2013; 19: 1131-1141; DOI: 10.12659/MSM.889469

17. Kilbourne ED. Influenza Pandemics of the 20th Century. Emerging Infectious Diseases. www.cdc.gov/eid • Vol. 12, No. 1, January 2006

18. Oxford JS et al. "A hypothesis: the conjunction of soldiers, gas, pigs, ducks, geese and horses in northern France during the Great War provided 
the conditions for the emergence of the "Spanish" influenza pandemic of 1918-1919" (PDF). Vaccine. 2005; 23 (7): 940-45. doi:10.1016/j.vaccine.2004.06.035. PMID 15603896

19. Jilani T et al. H1N1 Influenza (Swine Flu). https://www.ncbi.nlm.nih.gov/books/NBK51324 1/

20. Qiu W et al. The Pandemic and its Impacts. Health, Culture and Society. 2016-17; 9-10; DOI 10.5195/hcs.2017.221
The authors declare no conflict of interest and assert their intellectual copyrights to this work. Prof Dasgupta designed, analysed the evidence and wrote the article; Dr Crunkhorn analysed the evidence, peer reviewed and revised the text; both were responsible for the integrity of the work. No funding was involved in the study.

Figure 2: Artistic depiction of plague - Ingmar Bergman's The Seventh Seal (1957) where silhouettes in cinematic imagery were successfully used for the first time with plague appearing as a character in the film. Plague is the only pandemic that has found the most artistic expression. (Talia Felix has released this "Seventh Seal" image under Public Domain license, CCO Public

Domain https://www.publicdomainpictures.net/en/viewimag e.php?image $=47891$ \& picture $=$ seventh-seal)

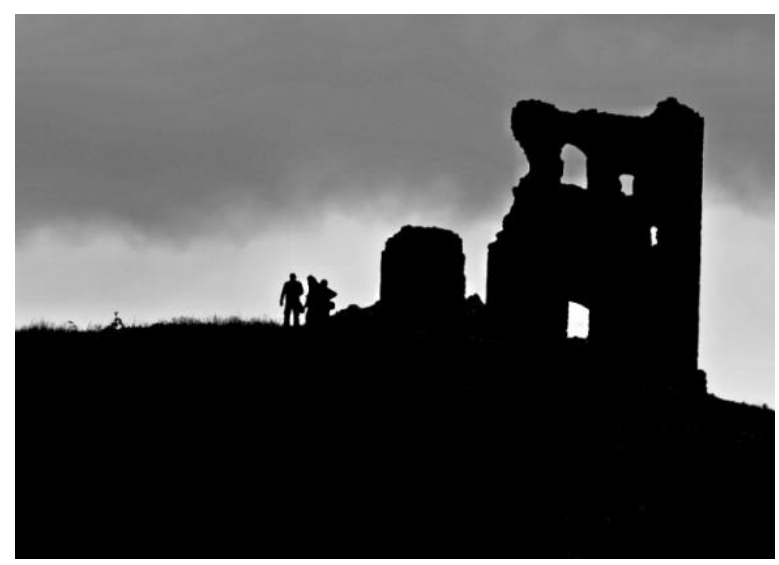

